\title{
PENGARUH INFLASI, KURS DAN SUKU BUNGA TERHADAP RISIKO SISTEMATIS SEBAGAI VARIABEL MEDIASI DAN IMPLIKASINYA TERHADAP HARGA SAHAM DENGAN PENERAPAN REGRESI DATA PANEL COMMON EFFECT
}

(Studi Empiris Pada Saham-Saham Jakarta Islamic Index Di Bursa Efek Indonesia Tahun 2013-2018)

\author{
Sunaryo \\ Program Studi Magister Manajemen, Fakultas Ekonomi dan Bisnis, \\ Universitas Islam As-syafi'iyah \\ sunaryo56@gmail.com
}

\begin{abstract}
The aims of this research are to examine the direct effect and indirect effect of Inflation, Exchange Rate, Interest Rate on Stock Price with Systematic Risk as an intervening variable. This research sample is shared in the sharia category in the JII group (Jakarta Islamic Index) listed on the Indonesia Stock Exchange (IDX) period 2013-2018 by using a purposive sampling method. There were 41 stocks selected as samples. The method of analysis used is Path Analysis, the development of panel data regression common effect. Using panel data regression with common effect analysis, it is known that the Inflation and Exchange Rate has a positive significant effect on Systematic Risk. However, Interest Rates have a significant negative effect on Systematic Risk. Systematic Risk has a significant negative effect on Stock Price. The path analysis results show that Systematic Risk mediates the effect of Inflation and Exchange Rates on the Stock price.
\end{abstract}

Keywords: Inflation, Exchange Rate, Interest Rate, Systematic Risk and Stock Price

\begin{abstract}
Abstrak
Tujuan dari penelitian ini adalah untuk menguji efek langsung dan efek tidak langsung dari Inflasi, Kurs dan Suku Bunga pada Harga Saham dengan Risiko Sistematis sebagai variabel intervening. Sampel penelitian ini adalah saham-saham dalam kategori syariah dalam kelompok JII (Jakarta Islamic Index) yang terdaftar di Bursa Efek Indonesia (BEI) periode 2013-2018 dengan menggunakan metode purposive sampling. Ada 41 saham yang dipilih sebagai sampel. Metode analisis yang digunakan adalah Path Analysis, pengembangan dari regresi data panel dengan common effect. Menggunakan regresi data panel dengan analisis common effect, diketahui bahwa Inflasi dan Kurs berpengaruh positif signifikan terhadap Risiko Sistematis. Namun Suku Bunga berpengaruh negatif signifikan terhadap Risiko Sistematis. Risiko Sistematis berpengaruh negatif signifikan terhadap Harga Saham. Hasil analisis jalur menunjukkan bahwa Risiko Sistematis memediasi pengaruh terhadap Inflasi dan Kurs terhadap harga Saham.
\end{abstract}

Kata kunci: Inflasi, Kurs, Suku Bunga, Risiko Sistematis dan Harga Saham 


\section{Pendahuluan}

\section{Latar Belakang Penelitian}

Dalam dunia bisnis dikenal dengan investasi. Investasi merupakan pengalokasian dana sekarang yang bertujuan mendapatkan laba di masa depan (Tandelilin, 2010). Menurut Halim (2005) investasi dapat dibedakan menjadi dua, yaitu: investasi pada aset finansial (financial assets) dan investasi aset-aset riil (real assets). Investasi pada asetaset fianansial dilakukan di pasar uang, misalnya berupa sertifikat deposito, commercial paper, surat berharga pasar uang dan lainnya. Investasi dapat juga dilakukan di pasar modal, misalnya berupa saham, obligasi, waran, opsi, dan lain-lain. Sedangkan investasi pada aset aset riil dapat berbentuk pembelian aset produktif, pendirian pabrik, pembukaan pertambangan, pembukaan perkebunan dan lainnya.

Di Indonesia para investor domestik maupun investor asing dapat melakukan investasi dalam bentuk saham di pasar modal yang dikenal dengan Bursa Efek Indonesia (BEI). Di Bursa Efek Indonesia terdapat 9 sektor perusahaan yang listing, yaitu (1) Pertanian, (2) Pertambangan, (3) Industri Dasar dan Kimia, (4) Aneka Industri, (5) Industri Barang Konsumsi, (6) Property, Real Estat \& Konstruksi Bangunan, (7) Infrakstruktur, Utilititas \& Transportasi, (8) Finansial, dan (9) Perdagangan Jasa \& Investasi. Sampai dengan akhir tahun 2018 perusahaan yang listing di BEI sebanyak 555 perusahaan.

Di BEI terdapat saham syariah yang dapat menjadi pilihan bagi investor yang memperhatikan penerapan syariat agama Islam atau saham yang berbasis syariah dalam kegiatan berinvestasi. Pengertian saham yang berbasis saham syariah berdasarkan undang-undang maupun peraturan OJK lainnya, yaitu ada dua jenis saham syariah yang diakui di pasar modal Indonesia. Pertama, saham yang dinyatakan memenuhi kriteria seleksi saham syariah berdasarkan peraturan OJK Nomor 35/POJK.04/2017 tentang Kriteria dan Penerbitan Daftar Efek Syariah, kedua adalah saham yang dicatatkan sebagai saham syariah oleh emiten atau perusahan publik syariah berdasarkan peraturan OJK no. 17/POJK.04/2015.

Indeks saham syariah yang digunakan sebagai indikator untuk mengamati pergerakan harga sahamnya adalah Jakarta Islamic Index (JII). JII sebagai indeks saham syariah diluncurkan pertama kali di pasar modal Indonesia pada tanggal 3 Juli 2000. Konstituen JII hanya terdiri dari 30 saham syariah paling likuid yang tercatat di BEI. BEI menentukan dan melakukan seleksi saham syariah yang menjadi konstituen JII sebagai berikut (sumber Fahmi, 2014:311) :

1. Saham dipilih harus sudah tercatat paling tidak 3 bulan terakhir, kecuali saham yang termasuk 10 kapitalisasi besar.

2. Mempunyai Rasio hutang terhadap Aktiva tidak lebih besar dari $90 \%$ dilaporan keuangan tahunan atau tengah tahun.

3. Dari yang masuk kriteria 1 dan 2, dipilih 60 saham dengan urutan rata-rata kapitalisasi pasar terbesar selama satu tahun terakhir.

4. Kemudian dipilih 30 saham dengan urutan tingkat likuiditas rata-rata nilai perdagangan regular selama tahun terakhir.

Pergerakan JII dapat digunakan sebagai acuan bagi investor maupun calon investor dalam berinvestasi di BEI dalam rangka untuk mendapatkan imbal hasil. Kebanyakan investor yang melakukan investasi saham di pasar modal mengharapkan untuk memperoleh return yang utama dalam bentuk capital gain. Investor harus menyadari bahwa di samping akan mendapatkan keuntungan dari berinvestasi, tidak 
menutup kemungkinan mereka juga akan mengalami kerugian. Keuntungan (return) dan kerugian (loss) tersebut sangat dipengaruhi oleh kemampuan atau keahlian investor dalam menganalisis keadaan harga saham. Informasi tentang perusahaan mana yang akan membawakan keuntungan atau kerugian bagi investor dapat ditinjau dari faktor-faktor yang mempengaruhi pergerakan harga saham JII, yaitu faktor internal dan faktor eksternal.

Perkembangan JII di BEI selama kurun waktu enam tahun disajikan pada tabel 1 berikut ini.

Tabel 1. Perkembangan JII Di Bursa Efek Indonesia Tahun 2013-2018

\begin{tabular}{lcccccc} 
& \multicolumn{6}{c}{ Tahun } \\
\cline { 2 - 7 } & $\mathbf{2 0 1 3}$ & $\mathbf{2 0 1 4}$ & $\mathbf{2 0 1 5}$ & $\mathbf{2 0 1 6}$ & $\mathbf{2 0 1 7}$ & $\mathbf{2 0 1 8}$ \\
\hline JII & 586.89 & 691.04 & 607.78 & 701.76 & 759.07 & 685.22 \\
\hline Sumber : BEI & & & & & &
\end{tabular}

Dari tabel 1 di atas tergambar JII yang mencerminkan harga saham syariah dari tahun 2013 sampai dengan tahun 2017 cenderung meningkat, hal ini menggambarkan terjadinya kenaikan harga saham syariah. Namun pada tahun 2018 JII mengalami penurunan dibandingkan tahun 2017, hal ini menggambarkan terjadinya penurunan harga saham syariah. Pada saat JII mengalami peningkatan bagi investor yang telah memiliki saham-saham syariah akan memperoleh keuntungan, sebaliknya pada saat JII mengalami penurunan bagi investor yang telah memiliki saham-saham syariah akan mengalami kerugian.

Menurut Alwi (2008) faktor-faktor yang mempengaruhi pergerakan harga saham yaitu internal dan eksternal. Faktor internal seperti pengumuman tentang pemasaran, produksi, penjualan seperti pengiklanan, rincian kontrak, perubahan harga, penarikan produk baru, laporan produksi, laporan keamanan produk, dan laporan penjualan, pengumuman pendanaan, pengumuman badan direksi manajemen, pengumuman pengambilalihan diversifikasi, pengumuman investasi, pengumuman ketenagakerjaan, dan pengumuman laporan keuangan perusahaan, peramalan laba sebelum akhir tahun fiskal dan setelah akhir tahun fiskal, Earning Per Share (EPS), Dividen Per Share (DPS), Price Earning Ratio, Net Profit Margin, Return on Assets (ROA), dan lain-lain. Sedangkan faktor eksternal seperti perubahan suku bunga tabungan dan deposito, kurs valuta asing, inflasi, serta berbagai regulasi dan deregulasi ekonomi yang dikeluarkan oleh pemerintah. Tandelilin (2010) mengemukakan harga saham sangat tergantung dari prospek keuntungan yang dimiliki perusahaan, dan keuntungan tersebut tergantung kondisi makro ekonomi seperti produk domestik bruto, tingkat pengangguran, inflasi, tingkat bunga, kurs Rupiah terhadap US dolar.

Faktor yang memengaruhi pergerakan atau volatilitas harga saham seperti yang diuraikan di atas pada dasar merupakan risiko yang dihadapi oleh investor. Menurut Sunariyah (2013) faktor makro dapat menimbulkan risiko saham yang disebut sebagai risiko sistematis. Risiko sistematis adalah risiko yang berkaitan dengan perubahan yang terjadi di pasar secara keseluruhan. Perubahan pasar tersebut akan mempengaruhi variabelitas return suatu investasi. Perkembangan risiko sistematis saham-saham syariah dalam JII yang di ukur dengan beta selama kurun waktu enam tahun disajikan pada tabel 2 berikut ini. 
Tabel 2. Perkembangan Rata-Rata Risiko Sistematis JII Di Bursa Efek Indonesia Tahun 2013-2018

\begin{tabular}{ccccccc}
\hline & \multicolumn{6}{c}{ Tahun } \\
\cline { 2 - 7 } & $\mathbf{2 0 1 3}$ & $\mathbf{2 0 1 4}$ & $\mathbf{2 0 1 5}$ & $\mathbf{2 0 1 6}$ & $\mathbf{2 0 1 7}$ & $\mathbf{2 0 1 8}$ \\
\hline Beta & 1.013 & 1.017 & 1.074 & 1.239 & 1.257 & 1.287 \\
\hline Sumber : Pefindo di olah & & & & &
\end{tabular}

Dari tabel 2 di atas tergambar beta saham-saham syariah di BEI mengalami peningkatan dari tahun 2013 sampai dengan tahun 2018.

Dari uraian teoritis di atas dapat disimpulkan bahwa terdapat keterkaitan antara pergerakan harga saham dengan risiko dan faktor yang memengaruhi harga saham dengan risiko. Dimana faktor makro ekonomi misalnya memengaruhi risiko sistematis dan pada akhirnya risiko sistematis akan memengaruhi harga saham.

Penelitian terdahulu yang berhubungan dengan inflasi, suku bunga dan kurs terhadap harga saham yang tercermin di JII seperti Kismawad (2013) menemukan, inflasi berpengaruh positif dan signifikan terhadap JII, suku bunga berpengaruh negatif dan signifikan terhadap JII, kurs berpengaruh negatif dan signifikan terhadap JII. Namun Utami dan Herlambang (2016) menemukan berbeda, inflasi berpengaruh negatif dan signifikan terhadap JII, suku bunga berpengaruh positif dan signifikan terhadap JII, kurs berpengaruh positif dan signifikan terhadap JII.

Penelitian terdahulu yang berhubungan dengan inflasi, suku bunga dan kurs terhadap risiko sistematis seperti Sarumaha (2017), menemukan inflasi berpengaruh negatif signifikan terhadap beta saham, sedangkan Kurs Rupiah/USD tidak berpengaruh positif signifikan terhadap beta saham, Ardwita (2016) menemukan inflasi dan kurs berpengaruh signifikan terhadap beta saham. Ferranti dan Yunita (2015) menemukan inflasi dan tingkat suku bunga tidak berpengaruh signifikan terhadap risiko sistematis. Pangemanan (2013) menemukan tingkat suku bunga berpengaruh positif dan signifikan terhadap risiko sistematis. Fitriawati (2009) menemukan suku bunga berpengaruh negatif signifikan terhadap risiko sistematis.

Penelitian terdahulu yang berhubungan dengan risiko sistematis harga saham seperti Agusto (2018), menemukan risiko sistematis tidak berpengaruh terhadap harga saham. Namun Rahmani dkk (2017) menemukan risiko sistematis (beta) berpengaruh negatif signifikan terhadap harga saham.

Dari uraian tersebut di atas tergambar data-data fenomena dilapangan menunjukkan bahwa harga saham syariah yang tercermin dalam JII menunjukkan penurunan dan risiko sistematis yang meningkat, disamping itu penelitian terdahulu yang tidak konsisten temuannya. Oleh karena itu penelitian ini selain mencari faktor penyebab yang signifikan memengaruhi risiko sistematis dan harga saham dalam JII dan juga perlu dilakukan pengujian lebih lanjut untuk mengetahui konsistensi temuan jika diterapkan pada kondisi lingkungan yang berbeda, dan juga pengembangan penelitian ini dengan mengunakan analisis jalur.

\section{Perumusan Masalah}

Atas dasar fenomena gap dan research gap, maka perlu dilakukan penelitian lanjutan dengan mengajukan lima pertanyaan penelitian : (1) Apakah inflasi berpengaruh terhadap risiko sistematis?, (2) Apakah kurs berpengaruh terhadap risiko sistematis?, (3) 
Apakah suku bunga berpengaruh terhadap risiko sistematis?, (4) Apakah risiko sistematis sebagai variabel mediasi berpengaruh terhadap harga saham?, (5) Apakah risiko sistematis berperan sebagai variabel mediasi pengaruh inflasi, kurs dan suku bunga terhadap harga saham?

\section{Tujuan Penelitian}

Tujuan penelitian ini untuk mengetahui, menganalisis dan memperoleh bukti empiris mengenai :

(1) Pengaruh inflasi terhadap risiko sistematis.

(2) Pengaruh kurs terhadap risiko sistematis.

(3) Pengaruh suku bunga terhadap terhadap risiko sistematis

(4) Pengaruh risiko sistematis sebagai variabel mediasi terhadap harga saham.

(5) Peran risiko sistematis sebagai variabel mediasi pengaruh inflasi, kurs dan suku terhadap harga saham.

\section{Manfaat Penelitian}

(1) Investor

Hasil penelitian ini diharapkan dapat bermanfaat bagi :

Secara praktis, hasil penelitian ini diharapkan dapat bermanfaat bagi investor di Pasar Modal sebagai informasi dalam mempertimbangkan keputusanya untuk investasi saham yang berbasis syariah.

(2) Akademik

Secara teoritis, hasil penelitian ini diharapkan dapat menjadi tambahan pengetahuan dan referensi. Disamping itu juga sebagai tambahan refensi bagi peneliti selanjutnya.

\section{Tinjauan Pustaka Dan Hipotesis}

\section{Landasan Teori}

\subsection{Inflasi}

Menurut Conway (2009), inflasi biasanya dinyatakan atas dasar tahunan. Oleh karena itu, tingkat inflasi sebesar tiga persen berarti bahwa harga di seluruh ekonomi secara keseluruhan adalah tiga persen lebih tinggi daripada 12 bulan sebelumnya. Menurut Fahmi (2014:67) inflasi adalah: "Suatu kejadian yang menggambarkan situasi dan kondisi di mana harga barang mengalami kenaikan dan nilai mata uang mengalami pelemahan". Menurut Sukirno (2011:165) inflasi adalah: "Kenaikan harga barang-barang yang bersifat umum dan terus-menerus".

Fahmi (2014:69) mengemukakan, jenis inflasi terdiri dari 4 jenis yaitu:

(1) Inflasi ringan (creeping inflation)

Disebut sebagai inflasi ringan karena skalanya inflasinya sangat kecil dengan skala inflasi $<10 \%$ per tahun.

(2) Inflasi moderat (moderate inflation)

Jenis inflasi ini moderat dianggap dapat mengganggu dan bahkan mengancam pertumbuhan ekonomi dengan skala inflasi $10-30 \%$ per tahun.

(3) Inflasi berat 
Inflasi berat merupakan inflasi yang menyebabkan sektor-sektor ekonomi mulai mengalami kelumpuhan kecuali yang dikuasai negara dengan skala inflasi 30$100 \%$ per tahun.

(4) Inflasi sangat berat (hyper inflation)

Jenis inflasi ini terjadi pada jaman perang dunia kedua, uang dicetak berlebihan karena kebutuhan perang dengan skala inflasi $>100 \%$ per tahun

\subsection{Kurs}

Nopirin (2012:163) mengemukakan, nilai tukar adalah: "Harga di dalam pertukaran dua macam mata uang yang berbeda, akan terdapat perbandingan nilai atau harga antara kedua mata uang tertentu, perbandingan nilai inilah yang disebut exchange rate". Sedangkan Salvatore (1997) mengemukakan : "Kurs atau Nilai Tukar adalah Harga suatu Mata Uang terhadap Mata Uang lainnya". Pengertian lain dari nilai tukar ditulis oleh Blanchard (2006), adalah "Nominal exchange rate as the price of the domestic currency in term of foreign currency".

Sukirno (2011:411) mengemukakan, jenis nilai tukar mata uang atau kurs valuta terdiri dari 4 jenis :

(1) Selling Rate (Kurs Jual)

Merupakan kurs yang ditentukan oleh suatu bank untuk penjualan valuta asing tertentu pada saat tertentu.

(2) Middle Rate (Kurs Tengah)

Merupakan kurs tengah antara kurs jual dan kurs beli valuta asing terhadap mata uang nasional, yang telah ditetapkan oleh bank sentral pada saat tertentu.

(3) Buying Rate (Kurs Beli)

Merupakan kurs yang ditentukan oleh suatu bank untuk pembelian valuta asing tertentu pada saat tertentu.

(4) Flat Rate (Kurs Rata)

Merupakan kurs yang berlaku dalam transaksi jual beli bank notes dan travellers cheque.

\subsection{Suku Bunga}

Atmaja (2008:20) mengemukakan : "pada dasarnya suku bunga merupakan harga yang dibayar sehubungan penggunaan dana atau modal". Tingkat bunga akan mempengaruhi keputusan individu dalam menentukan pilihan apakah membelanjakan uangnya atau menabung.

Sunariyah (2011:81) mengemukakan : fungsi tingkat suku bunga, yaitu :

(1) Sebagai daya tarik bagi para penabung yang mempunyai dana lebih untuk diinvestasikan.

(2) Suku bunga dapat digunakan sebagai alat moneter dalam rangka mengendalikan penawaran dan permintaan uang yang beredar dalam suatu perekonomian. Misalnya, pemerintah mendukung pertumbuhan suatu sektor industri tertentu apabila perusahaan-perusahaan dari industri tersebut akan meminjam dana. Maka pemerintah memberi tingkat bunga yang lebih rendah dibandingkan sektor lain.

(3) Pemerintah dapat memanfaatkan suku bunga untuk mengontrol jumlah uang beredar. Ini berarti, pemerintah dapat mengatur sirkulasi uang dalam suatu perekonomian. 
Pemerintah dalam ini Bank Indonesia sebagai Bank Sentral apabila menaikan suku bunga yang akan diikuti oleh bank umum, masyarakat diharapkan tertarik untuk menyimpan uang di bank, sehingga dengan demikian jumlah uang yang beredar berkurang. Selain itu kenaikan suku bunga tabungan akan meningkatkan suku bunga kredit, dengan naiknya suku bunga kredit maka minat untuk mengajukan kredit akan berkurang. Di Indonesia kebijakan moneter terhadap penyesuaian tingkat suku bunga tersebut dilakukan melalui penetapan BI rate (suku bunga acuan).

\subsection{Risiko Sistematis}

Keown et al. (2004:206) mengemukakan : "risiko sistematis adalah risiko yang terkait dengan pasar (risiko yang tidak dapat didiversifikasikan)"'. Sedangkan Fahmi (2014:461) mengemukakan : "Risiko sistematis (systematic risk) adalah risiko yang tidak bisa didiversifikasikan atau dengan kata lain risiko yang sifatnya mempengaruhi secara menyeluruh. Contohnya krisis moneter pada tahun 1997. Systematic risk disebut juga dengan market risk atau risiko umum".

Jogiyanto (2017:474) mengemukakan : "Beta adalah pengukur risiko sistematik dari suatu sekuritas atau portofolio relatif terhadap risiko pasar.

Husnan (2005) mengemukakan, faktor-faktor yang diidentifikasikan memengaruhi nilai beta adalah :

(1) Cyclicality. Faktor ini menunjukkan seberapa jauh suatu perusahaan dipengaruhi oleh konjungtur perekonomian. Jika kondisi perekonomian membaik, semua perusahaan akan merasakan dampak positifnya. Demikian pula pada saat resesi semua perusahaan akan merasakan dampak negatifnya.

(2) Operating leverage. Operating leverage menunjukkan porsi biaya perusahaan yang merupakan biaya tetap. Semakin tinggi biaya tetap maka semakin tinggi operating leverage, dan beta akan cenderung tinggi.

(3) Financial leverage. Perusahaan yang mempunyai hutang adalah yang mempunyai financial leverage. Semakin besar porsi hutangnya maka semakin tinggi financial leverage, dan beta akan cenderung tinggi.

\subsection{Harga Saham}

Nilai pasar (market value) merupakan nilai saham di pasar saham Jogiyanto (2017:199). Lebih lanjut saham Jogiyanto (2017:2008) mengemukakan: "nilai pasar (market value) berbeda dengan nilai buku. Jika nilai buku merupakan nilai yang tercatat pada saat saham dijual oleh perusahaan, maka nilai pasar adalah harga saham yang terjadi di pasar bursa pada saat tertentu yang ditentukan oleh pelaku pasar. Nilai pasar ini ditentukan oleh permintaan dan penawaran saham bersangkutan di pasar bursa".

Menurut Fahmi (2014:329) terdapat beberapa faktor yang mempengaruhi naik turunnya harga saham yaitu :

(1) Kondisi mikro dan makro ekonomi.

(2) Keputusan perusahaan dalam memutuskan untuk ekspansi (perluasan usaha), seperti membuka kantor cabang (brand office), kantor cabang pembantu (sub brand office) baik yang dibuka di domestik maupun luar negeri. 
(3) Pergantian direksi secara tiba-tiba.

(4) Adanya direksi atau komisaris perusahaan yang terlibat dalam tindak pidana dan kasusnya sudah masuk ke pengadilan.

(5) Kinerja perusahaan yang terus mengalami penurunan dalam setiap waktunya.

(6) Risko sistematis, yaitu risiko yang terjadi secara menyeluruh dan telah ikut menyebabkan perusahaan ikut terlibat.

(7) Efek psikologi pasar yang ternyata mampu menekan kondisi teknikal jual beli saham.

\section{Kerangka Pemikiran Teoritis dan Perumusan Hipotesis}

Pengaruh Inflasi terhadap Risiko Sistematis. Seperti yang diungkapkan oleh Husnan (2005) salah satu faktor yang memengaruhi nilai beta adalah Cyclicality. Faktor ini menunjukkan seberapa jauh suatu perusahaan dipengaruhi oleh konjungtur perekonomian. Jika kondisi perekonomian memburuk, misalnya seperti menurut Tandelilin (2010:342), terlalu tingginya inflasi akan menyebabkan turunnya pendapatan riil yang diperoleh investor dari investasi, maka akan merupakan sinyal negatif, sehingga menyebabkan risiko sistematis meningkat. Sebaliknya, jika inflasi suatu negara mengalami penurunan, maka hal ini akan merupakan sinyal yang positif bagi investor seiring dengan turunnya risiko daya beli uang dan risiko penurunan pendapatan riil, sehingga menyebabkan risiko sistematis menurun. Penelitian terdahulu seperti Ardwita (2016) menemukan, inflasi berpengaruh positif dan signifikan terhadap risiko sistematis. Atas dasar teori dan hasil penelitian terdahulu tersebut, maka hipotesis pertama dalam penelitian ini sebagai berikut:

$\mathrm{H} 1$ : Inflasi berpengaruh positif terhadap risiko sistematis.

Pengaruh Kurs terhadap Risiko Sistematis. Menurut Tandelilin (2010), salah satu faktor makro ekonomi yang berpengaruh terhadap investasi di suatu negara adalah nilai tukar mata uang (exchange rate). Menguatnya kurs rupiah terhadap mata uang asing akan menurunkan biaya impor bahan baku untuk produksi, dan akan menurunkan tingkat suku bunga yang berlaku. Bagi investor sendiri, depresiasi rupiah terhadap dollar menandakan bahwa prospek perekonomian Indonesia suram (Sunariyah, 2013). Sebab depresiasi rupiah dapat terjadi apabila faktor fundamental perekonomian Indonesia tidaklah kuat, sehingga dolar Amerika akan menguat dan akan menurunkan kinerja di BEI, sehingga merupakan sinyal negatif bagi investor, sehingga menyebabkan risiko sistematis meningkat. Penelitian terdahulu seperti Ardwita (2016) menemukan, nilai tukar mata uang berpengaruh positif dan signifikan terhadap risiko sistematis. Atas dasar teori dan hasil penelitian terdahulu tersebut, maka hipotesis kedua dalam penelitian ini sebagai berikut:

$\mathrm{H} 2$ : Kurs berpengaruh positif terhadap risiko sistematis.

Pengaruh Suku Bunga terhadap Risiko Sistematis. Perubahan suku bunga bisa mempengaruhi variabilitas return suatu investasi. Perubahan suku bunga akan mempengaruhi harga saham secara terbalik, citeris paribus. Artinya, jika suku bunga meningkat, maka harga saham akan turun, citeris paribus. Demikian pula sebaliknya bunga (Tandelilin, 2010:103). Risiko tingkat bunga, merupakan risiko yang timbul akibat perubahan tingkat bunga yang berlaku di pasar modal (Halim, 2005). Perubahan (volatilitas) harga saham tersebut akan meningkatkan risiko. 
Dalam penelitian ini suku bunga yang berpengaruh negatif terhadap harga saham dan akhirnya berpengaruh positif terhadap risiko sistematis saham-saham yang berbasis syariah, citeris paribus artinya tetap menggunakan asumsi dasarnya, karena kondisi kepemilkan saham di pasar modal Indonesia hampir 60 persen dikuasai investor asing mengakibatkan kerentanan fluktuasi ISSI yang lebih besar pada posisi net sell oleh investor asing (Tangjitprom : 2012 dari sumber Republika.co.id). Penelitian terdahulu seperti Pangemanan (2013) menemukan, suku bunga berpengaruh positif dan signifikan terhadap risiko sistematis.

Atas dasar teori, pengembangan asumsi dan hasil penelitian terdahulu tersebut, maka hipotesis ketiga dalam penelitian ini sebagai berikut:

H3: Suku Bunga berpengaruh positif terhadap risiko sistematis.

Pengaruh Risiko Sistematis terhadap Harga Saham. Menurut Fahmi (2014:329) faktor yang mempengaruhi naik turunnya harga saham diantaranya risiko sistematis. Keown et al. (2004:206) mengemukakan : "risiko sistematis adalah risiko yang terkait dengan pasar (risiko yang tidak dapat didiversifikasikan)". Penelitian terdahulu seperti Rahmani dkk (2017) menemukan risiko sistematis (beta) berpengaruh negatif signifikan terhadap harga saham. Atas dasar teori dan hasil penelitian terdahulu tersebut, maka hipotesis keempat dalam penelitian ini sebagai berikut:

H4: Risiko Sistematis berpengaruh negatif terhadap harga saham.

Risiko Sistematis Memediasi Pengaruh Variabel Makro Ekonomi terhadap Harga Saham. Keown et al. (2004:206) mengemukakan : "risiko sistematis adalah risiko yang terkait dengan pasar (risiko yang tidak dapat didiversifikasikan). Bagian dari variasi pengembalian investasi yang tidak bisa dihapus melalui pendiversifikasian investor. Variasi ini diakibatkan oleh faktor yang mempengaruhi semua saham". Husnan (2005) mengemukakan, faktor yang memengaruhi risiko sistematis diantaranya Cyclicality. Faktor ini menunjukkan seberapa jauh suatu perusahaan dipengaruhi oleh konjungtur perekonomian. Jika kondisi perekonomian membaik, semua perusahaan akan merasakan dampak positifnya yang menyebabkan risiko sistematis menurun, sehingga berdampak positif terhadap harga saham. Demikian pula pada saat resesi semua perusahaan akan merasakan dampak negatifnya yang menyebabkan risiko sistematis meningkat, sehingga berdampak negatif terhadap harga saham. Penelitian terdahulu seperti Pangemanan (2013) yang menemukan tingkat suku bunga berpengaruh positif dan signifikan terhadap risiko sistematis. Rahmani dkk. (2017) menemukan risiko sistematis (beta) berpengaruh negatif signifikan terhadap harga saham. Atas dasar teori dan hasil penelitian terdahulu tersebut, maka hipotesis kelima dalam penelitian ini sebagai berikut:

H5: Risiko sistematis memediasi pengaruh variabel Inflasi, Kurs dan Suku Bunga terhadap harga saham. 


\section{Kerangka Pemikiran Teoritis}

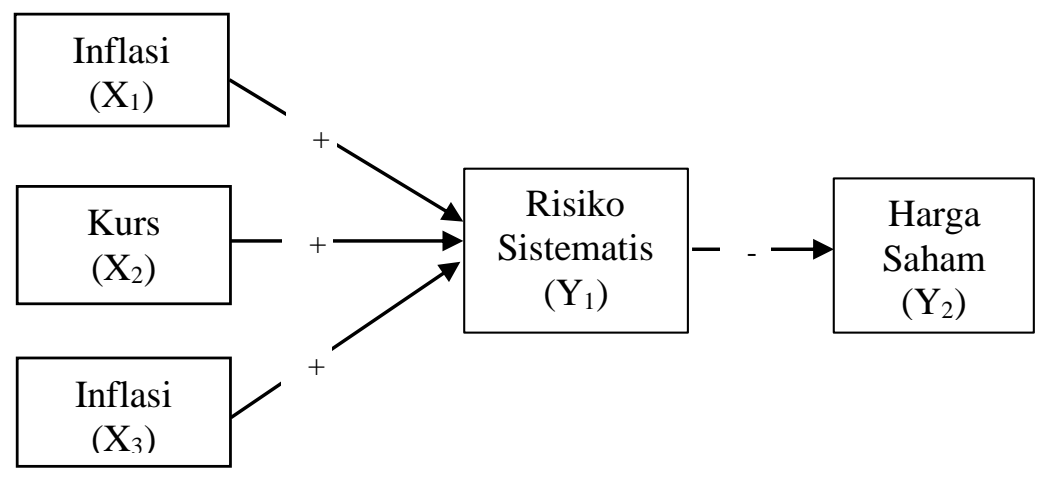

Gambar 1. Kerangka Pemikiran Teoritis

\section{Metode Penelitian}

Populasi penelitian ini adalah saham-saham dalam kategori syariah dalam kelompok JII (Jakarta Islamic Index). Teknik sampling yang digunakan adalah purposive sampling dengan kriteria saham yang masuk 30 kelompok JII dari tahun 2013 - 2018 sekurang-kurang empat tahun. Data diperoleh berdasarkan publikasi Bursa Efek Indonesia. Diperoleh jumlah sampel sebanyak 41 saham syariah yang disajikan pada tabel 3 berikut ini.

Tabel 3. Daftar Saham Terpilih Sebagai Sampel

\begin{tabular}{|c|c|l|}
\hline No. & Kode & \multicolumn{1}{|c|}{ Nama Perusahaan } \\
\hline 1 & AALI & Astra Agro Lestari Tbk. \\
\hline 2 & ADRO & Adaro Energy Tbk. \\
\hline 3 & AKRA & AKR Corporindo Tbk. \\
\hline 4 & ANTM & Aneka Tambang (Persero) Tbk. \\
\hline 5 & ASII & Astra International Tbk. \\
\hline 6 & ASRI & Alam Sutera Realty Tbk \\
\hline 7 & BKSL & Sentul City Tbk. \\
\hline 8 & BMTR & Global Mediacom Tbk. \\
\hline 9 & BRPT & Barito Pacific Tbk. \\
\hline 10 & BSDE & Bumi Serpong Damai Tbk. \\
\hline 11 & CPIN & Charoen Pokphand Indonesia Tbk \\
\hline 12 & CTRA & Ciputra Development Tbk. \\
\hline 13 & EXCL & XL Axiata Tbk. \\
\hline 14 & HRUM & Harum Energy Tbk \\
\hline 15 & ICBP & Indofood CBP Sukses Makmur Tbk. \\
\hline 16 & INCO & Vale Indonesia Tbk. \\
\hline 17 & INDF & Indofood Sukses Makmur Tbk. \\
\hline 18 & INDY & Indika Energy Tbk. \\
\hline 19 & INTP & Indocement Tunggal Prakasa Tbk. \\
\hline 20 & ITMG & Indo Tambangraya Megah Tbk. \\
\hline 21 & JSMR & Jasa Marga Tbk \\
\hline 22 & KLBF & Kalbe Farma Tbk. \\
\hline 23 & LPKR & Lippo Karawaci Tbk. \\
\hline 24 & LSIP & PP London Sumatra Indonesia Tbk. \\
\hline 25 & LPPF & Matahari Department Store Tbk. \\
\hline 26 & MAPI & Mitra Adiperkasa Tbk \\
\hline
\end{tabular}




\begin{tabular}{|c|c|l|}
\hline No. & Kode & \multicolumn{1}{c|}{ Nama Perusahaan } \\
\hline 27 & MNCN & Media Nusantara Citra Tbk. \\
\hline 28 & MPPA & Matahari Putra Prima Tbk. \\
\hline 29 & MYRX & Hanson International Tbk. \\
\hline 30 & PGAS & Perusahaan Gas (Persero) Tbk \\
\hline 31 & PTBA & Tambang Batubara Bukit Asam (Persero) Tbk. \\
\hline 32 & PTPP & PP (Persero) Tbk. \\
\hline 33 & PWON & Pakuwon Jati Tbk. \\
\hline 34 & SCMA & Surya Citra Media Tbk. \\
\hline 35 & SMGR & Semen Indonesia (Persero) Tbk. \\
\hline 36 & SMRA & Summarecon Agung Tbk. \\
\hline 37 & TLKM & Telekomunikasi Indonesia (Persero) Tbk. \\
\hline 38 & TPIA & Chandra Asri Petrochemical Tbk. \\
\hline 39 & UNTR & United Tractors Tbk. \\
\hline 40 & UNVR & Unilever Indonesia Tbk. \\
\hline 41 & WIKA & Wijaya Karya (Persero) Tbk. \\
\hline
\end{tabular}

Tabel 4. Definisi Operasional Variabel

\begin{tabular}{|c|c|c|c|}
\hline Variabel & Konsep & Operasional Variabel & Skala \\
\hline Inflasi & $\begin{array}{l}\text { Kenaikan harga barang-barang } \\
\text { yang bersifat umum dan terus- } \\
\text { menerus }\end{array}$ & $\begin{array}{l}\text { Data yang digunakan dalam } \\
\text { penelitian ini adalah inflasi akhir } \\
\text { tahun } 2013 \text { hingga Desember } \\
\text { 2018. Dalam satuan persen }\end{array}$ & Rasio \\
\hline Kurs & $\begin{array}{l}\text { Kurs atau Nilai Tukar adalah } \\
\text { Harga suatu Mata Uang terhadap } \\
\text { Mata Uang lainnya }\end{array}$ & $\begin{array}{l}\text { Data yang dipakai dalam } \\
\text { penelitian ini adalah kurs tengah } \\
\text { (middle rate) antara kurs jual dan } \\
\text { kurs beli mata uang rupiah } \\
\text { terhadap dollar Amerika Serikat } \\
\text { yang ditetapkan oleh Bank } \\
\text { Indonesia. Data yang digunkan } \\
\text { dalam penelitian ini adalah kurs } \\
\text { akhir tahun 2013 hingga } \\
\text { Desember } 2018 \\
\text { Kurs =Ln (Rp terhadap USD) }\end{array}$ & Rasio \\
\hline Suku Bunga & $\begin{array}{l}\text { Suku bunga merupakan harga } \\
\text { yang dibayar sehubungan } \\
\text { penggunaan dana atau modal }\end{array}$ & $\begin{array}{l}\text { Tingkat BI Rate adalah tingkat } \\
\text { suku bunga yang ditetapkan oleh } \\
\text { Bank Indonesia dalam periode } \\
\text { tertentu. Data yang digunkan } \\
\text { dalam penelitian ini adalah BI rate } \\
\text { akhir tahun } 2013 \text { hingga } \\
\begin{array}{l}\text { Desember 2018. Dalam satuan } \\
\text { persen }\end{array}\end{array}$ & Rasio \\
\hline Risiko Sistematis & $\begin{array}{l}\text { Risiko sistematis adalah } \\
\text { yang terkait dengan pasar } \\
\text { yang risiko } \\
\text { didiversifikasikan }\end{array}$ & $\begin{array}{l}\text { Beta adalah pengukur risiko } \\
\text { sistematik. } \\
\beta \mathrm{i}=\frac{\sigma \mathrm{iM}}{\sigma^{2} \mathrm{M}} \\
\text { Dalam satuan indeks }\end{array}$ & Rasio \\
\hline Harga Saham & $\begin{array}{l}\text { Nilai pasar (market value) } \\
\text { merupakan nilai saham di pasar } \\
\text { saham Bursa Efek Indonesia }\end{array}$ & $\begin{array}{l}\text { Harga saham penutupan akhir } \\
\text { tahun } 2013 \text { hingga Desember } \\
2018 \\
\text { Harga Saham =Ln (Rp Harga } \\
\text { saham) }\end{array}$ & Rasio \\
\hline
\end{tabular}


Metode analisis yang digunakan adalah model regresi data panel common effect dengan General Leash Square dengan formula berikut:

$$
\begin{aligned}
& \mathrm{Y} 1_{\mathrm{it}}=\beta_{0 \mathrm{i}}+\beta_{1} \mathrm{X} 1_{\mathrm{it}}+\beta_{2} \mathrm{X} 2_{\mathrm{it}}+\beta_{3} \mathrm{X} 3_{\mathrm{it}}+\varepsilon_{\mathrm{it}} \rightarrow \text { Model } 1 \text { Risiko Sistematis } \\
& \mathrm{Y} 2_{\mathrm{it}}=\beta_{0}+\beta_{1} \mathrm{X} 1_{\mathrm{it}}+\beta_{2} \mathrm{X} 2_{\mathrm{it}}+\beta_{3} \mathrm{X} 3_{\mathrm{it}}+\beta_{4} \mathrm{Y} 1_{\mathrm{it}}+\varepsilon_{2 \mathrm{it}} \rightarrow \text { Model } 2 \text { Harga Saham }
\end{aligned}
$$

Keterangan:

$\beta_{0 \mathrm{i}}=$ Konstanta

Y1 = Risiko Sistematis; Y2 = Harga Saham; X1 = Inflasi; X2 = Kurs; X3= BI Rate

$\mathrm{i}=$ saham-saham, $\mathrm{t}=$ waktu, $\varepsilon=$ Error/variabel gangguan

\section{Hasil Penelitian Dan Pembahasan}

Hasil Penelitian. Penelitian ini menggunakan path analysis, analisis dimulai terlebih dahulu dicari persamaan regresi untuk mengetahui pengaruh Inflasi, Kurs dan Suku Bunga terhadap Risiko Sistematis, dilanjutkan analisis pengaruh Inflasi, Kurs dan Suku Bunga terhadap Harga Saham melalui Risiko Sistematis. Berdasarkan pengolahan data dengan software Eviews9 dihasilkan ringkasan hasil pengujian regresi data panel dengan metode common effect sebagai berikut :

Tabel 5. Regresi Model 1 (Risiko Sistematis)

Dependent Variable: Beta

\begin{tabular}{crrrr}
\hline \hline \multicolumn{1}{c}{ Variable } & Coefficient & Std. Error & t-Statistic & Prob. \\
\hline \hline C & -23.28910 & 6.511837 & -3.576426 & 0.0004 \\
INFLASI & 4.744263 & 1.770839 & 2.679104 & 0.0079 \\
KURS & 2.612220 & 0.683041 & 3.824398 & 0.0002 \\
BI Rate & -8.855113 & 1.607998 & -5.506919 & 0.0000 \\
\hline \hline R-squared & 0.272364 & & & \\
Adjusted R-squared & 0.263035 & & & \\
F-statistic & 29.19645 & & & \\
Prob(F-statistic) & 0.000000 & & & \\
\hline \hline
\end{tabular}

Tabel 6. Regresi Model 2 (Harga Saham)

Dependent Variable: Price

\begin{tabular}{crrrr}
\hline \hline Variable & Coefficient & Std. Error & t-Statistic & Prob. \\
\hline \hline C & 9.356060 & 20.37584 & 0.459174 & 0.6465 \\
BETA & -0.777961 & 0.105268 & -7.390274 & 0.0000 \\
INFLASI & 1.397579 & 5.881651 & 0.237617 & 0.8124 \\
KURS & -0.048102 & 2.137158 & -0.022508 & 0.9821 \\
Bi Rate & -3.461146 & 4.771337 & -0.725404 & 0.4689 \\
\hline \hline R-squared & 0.204769 & & & \\
Adjusted R-squared & 0.191117 & & & \\
F-statistic & 14.99917 & & & \\
Prob(F-statistic) & 0.000000 & & & \\
\hline \hline
\end{tabular}


Berdasarkan tabel 5 dan 6 dapat dirumuskan bersamaan model regresi data panel sebagai berikut:

Model 1 (Risiko Sistematis) :

$\mathrm{Y} 1=-23.289+4.7442 \mathrm{X} 1+2.612 \mathrm{X} 2-8.855 \mathrm{X} 3$

Model 2 (Harga Saham) :

$\mathrm{Y} 2=9.356-0.777 \mathrm{Y} 1+1.397 \mathrm{X} 1-0.048 \mathrm{X} 2-3.461 \mathrm{X} 3$

\section{Uji Signifikansi Simultan (Uji Statistik F)}

Dari tabel 5 untuk model 1 (Risiko Sistematis) terlihat hasil perhitungan diperoleh nilai $F$ sebesar 29.196 dan nilai signifikansi sebesar 0.0000 yang lebih kecil dari 0.05. Maka, dapat disimpulkan bahwa model 1 memenuhi Goodness of Fit dan layak untuk digunakan sebuah model.

Dari tabel 6 untuk model 2 (Harga Saham) terlihat hasil perhitungan diperoleh nilai $\mathrm{F}$ sebesar 14.999 dan nilai signifikansi sebesar 0.000 yang lebih kecil dari 0,05. Maka, dapat disimpulkan bahwa model 2 memenuhi Goodness of Fit dan layak untuk digunakan sebuah model.

\section{Koefisien Determinasi $\left(\mathbf{R}^{2}\right)$}

Dari tabel 5 terlihat nilai koefisien determinasi $\left(R^{2}\right)$ sebesar 0.2723 atau $27.23 \%$ yang menunjukkan bahwa $27.23 \%$ variasi Risiko Sistematis (Y1) dapat dijelaskan dengan variasi variabel bebas X1, X2 dan X3, sedangkan selebihnya yakni sebesar $72.77 \%$ dijelaskan oleh variabel lain diluar model. Sedangkan untuk koefisien determinasi model Harga Saham (tabel 6) sebesar 0.2047 atau $20.47 \%$ yang menunjukkan bahwa $20.47 \%$ variasi Harga Saham dapat dijelaskan dengan variasi variabel bebas Y1, X1, X2 dan X3, sedangkan selebihnya yakni sebesar $79.53 \%$ dijelaskan oleh variabel lain diluar model.

Berdasarkan pengujian terhadap koefisien regresi metode regresi data panel dengan model common effect secara parsial menggunakan uji-t dapat dibuktikan untuk modal 1 (Resiko Sistematis) bahwa X1 (Inflasi) berpengaruh positif signifikan terhadap Risiko Sistematis (Y1) dengan nilai probabilitasnya sebesar 0.0079 lebih kecil dari $\alpha=$ 0.05. X2 (Kurs) berpengaruh positif signifikan terhadap Risiko Sistematis (Y1) dengan nilai probabilitasnya sebesar 0.0002 lebih kecil dari $\alpha=0.05$. X3 (BI Rate) berpengaruh negatif signifikan terhadap Risiko Sistematis (Y1) dengan nilai probabilitasnya sebesar 0.0000 lebih kecil dari $\alpha=0.05$. Untuk modal 2 (Harga Saham) Y1 (Risiko Sistematis) berpengaruh negatif signifikan terhadap Y2 (Harga Saham) dengan nilai probabilitasnya masing-masing sebesar 0.0000 lebih kecil dari $\alpha=0.05$. Sedangkan X1 (Inflasi), X2 (Kurs) dan X3 (BI Rate) berpengaruh tidak signifikan terhadap Harga Saham (Y2) dengan nilai probabilitasnya lebih besar dari $\alpha=0.05$.

Dari koefisien persamaan regresi model 1 (Risiko Sistematis) dan 2 (Harga Saham) dapat digunakan untuk mencari pengaruh langsung Inflasi, Kurs dan BI Rate terhadap Harga Saham dan pengaruh tidak langsung Inflasi, Kurs dan BI Rate terhadap Harga Saham melalui memediasi pengaruh Risiko Sistematis dan secara ringkas nilai koefisien disajikan pada tabel 7 berikut ini. 
Tabel 7.

Ringkasan Hasil Output Tabel 4 dan 5 Analisis Jalur

\begin{tabular}{lccc}
\hline Regresi & Koefisien & Prob. & Jalur \\
\hline $\mathrm{X} 1 \rightarrow \mathrm{Y} 1$ & 4.744263 & 0.0347 & $\mathrm{P} 1$ \\
\hline $\mathrm{X} 2 \rightarrow \mathrm{Y} 1$ & 2.612220 & 0.0008 & $\mathrm{P} 2$ \\
\hline $\mathrm{X} 3 \rightarrow \mathrm{Y} 1$ & -8.855113 & 0.0001 & $\mathrm{P} 3$ \\
\hline $\mathrm{X} 1 \rightarrow \mathrm{Y} 2$ & 1.397579 & 0.8124 & $\mathrm{P} 4$ \\
\hline $\mathrm{X} 2 \rightarrow \mathrm{Y} 2$ & -0.048102 & 0.9821 & $\mathrm{P} 5$ \\
\hline $\mathrm{X} 3 \rightarrow \mathrm{Y} 2$ & -3.461146 & 0.4689 & $\mathrm{P} 6$ \\
\hline $\mathrm{Y} 1 \rightarrow \mathrm{Y} 2$ & -0.777961 & 0.0000 & $\mathrm{P} 7$ \\
\hline
\end{tabular}

\section{Analisis Jalur}

Tujuan dari analisis jalur adalah untuk menganalisis kekuatan pengaruh baik pengaruh langsung, tidak langsung, maupun pengaruh total variabel eksogen terhadap variabel endogen. Berdasarkan daya koefsien seperti yang disajikan tabel 6 dapat dihitung pengaruh langsung, tidak langsung, dan pengaruh total dengan model analisis jalur yang digambarkan sebagai berikut:

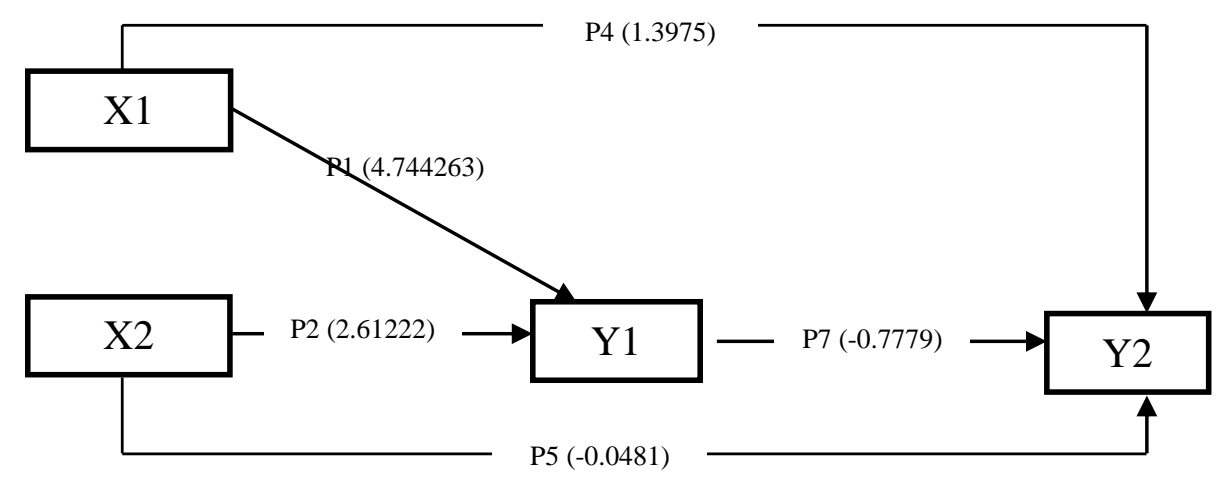

Gambar 2

Model Analisis Jalur

Dari gambar 2 variabel X3 (BI Rate) tidak dimasukan sebagai variabel jalur, karena pengaruh Suku Bunga yang diproksi dengan BI Rate terhadap Risiko Sistematis tidak sesuai dengan hipotesis.

X1(Inflasi) secara langsung berpengaruh terhadap Y2 Harga Saham sebesar 1.3975 dan berpengaruh tidak langsung terhadap Harga Saham sebesar 3.7139 (4.74426 x 0.7779). Total pengaruh Inflasi terhadap Harga Saham $=1.3975+3.7139=5.1114$. Besarnya koefisien pengaruh tidak langsung yang lebih besar daripada koefisien pengaruh langsung, maka dapat disimpulkan Y1 (Risiko Sistematis) memediasi pengaruh X1 (Inflasi) terhadap Y2 (Harga Saham).

X2 (Kurs) secara langsung berpengaruh terhadap Y2 Harga Saham sebesar 0.0481 dan berpengaruh tidak langsung terhadap Harga Saham sebesar 2.032 (2.6122 x 0.7779). Total pengaruh Inflasi terhadap Harga Saham $=0.0481+2.032=2.0801$. Besarnya koefisien pengaruh tidak langsung yang lebih besar daripada koefisien pengaruh langsung, maka dapat disimpulkan bahwa Y1 (Risiko Sistematis) memediasi pengaruh X2 (Kurs) terhadap Y2 (Harga Saham). 


\section{Sobel Test}

Ghozali (2014) mengemukakan, Sobel Test digunakan untuk lebih memastikan hubungan langsung dan tidak langsung antara variabel independen terhadap variabel dependen melalui variabel intervening. Adapun langkah-langkah yang harus dilakukan untuk menguji pengaruh tidak langsung menggunakan sobel test adalah sebagai berikut:

(1) Uji signifikansi indirect effec tab dilakukan berdasarkan rasio antara koefisien $\boldsymbol{a} \boldsymbol{b}$ dengan standard error-nya yang akan menghasilkan nilai z statistik (z-value). Standard error koefisien $\boldsymbol{a b}(\mathbf{S a b})$ dihitung berdasarkan versi Aroian dari Sobel test yang dipopulerkan dan direkomendasikan oleh Baron and Kenny (1986) dengan formula :

$$
z \text {-value }=\frac{\mathrm{ab}}{\sqrt{\mathrm{b}^{2} \mathrm{Sa}^{2}+\mathrm{a}^{2} \mathrm{Sb}^{2}+\mathrm{Sa}^{2} \mathrm{Sb}^{2}}}
$$

Keterangan:

$\boldsymbol{a} \boldsymbol{b}$ adalah koefisien indirect effet yang diperoleh dari perkalian antara direct effect $\boldsymbol{a}$ dan $\boldsymbol{b}$.

$\boldsymbol{a}$ adalah koefisien direct effect independen (X) terhadap mediator (M).

$\boldsymbol{b}$ adalah koefisien direct effect mediator (M) terhadap dependen (Y).

$\boldsymbol{S a}$ adalah standard error dari koefisien $\boldsymbol{a}$.

$\boldsymbol{S b}$ adalah standard error dari koefisien $\boldsymbol{b}$.

(2) Jika $\boldsymbol{z}$-value dalam harga mutlak $>1,96\left(\mathrm{Z}_{\text {tabel }}=\mathrm{Z}_{\alpha / 2}=\mathrm{Z}_{0,025}\right)$ atau tingkat signifikansi statistik z $(\boldsymbol{p}$-value $)<0.05$, berarti indirect effect atau pengaruh tak langsung variabel independen terhadap variabel dependen melalui mediator, signifikan pada taraf signifikansi 0.05 (Preacher and Hayes., 2004 dalam Ghozali, 2014).

$\boldsymbol{S} \boldsymbol{a}$ adalah standard error dari koefisien $\boldsymbol{a}(\mathrm{X} 1$ terhadap Y1) $=1.770839$

$\mathbf{b}=$ Koefisien pengaruh Y1 terhadap Y2 $=0.105268$

$\mathbf{a}=$ Koefisien pengaruh $\mathrm{X} 1$ terhadap $\mathrm{Y} 1=4.744263$

$\boldsymbol{S} \boldsymbol{b}$ adalah standard error dari koefisien $\boldsymbol{b}$ (Y1 terhadap Y2) $=0.084513$

$\boldsymbol{S a}$ adalah standard error dari koefisien $\boldsymbol{a}(\mathrm{X} 2$ terhadap Y1) $=0.683041$

$\mathbf{a}=$ Koefisien pengaruh X2 terhadap Y1 $=2.612220$

Berdasarkan perhitungan dengan formula Sobel yang pengolahannya menggunakan Sobel Test Calculator diketahui bahwa X1 (Inflasi) terhadap Y2 (Harga Saham) melalui Y1 (Risiko Sistematis) diperoleh nilai $z$-value $=2.5187>1.96$ atau z $(p$ value) $=0.00588<0.05$, maka dapat disimpulkan bahwa Y1 (Risiko Sistematis) memediasi pengaruhnya terhadap Y2 (Harga Saham). Pengujian dengan Sobel Test ini sesuai dengan pengujian cara perkalian koefisien seperti di atas.

Selanjutnya untuk X2 (Kurs) terhadap Y2 (Harga Saham) melalui Y1 (Risiko Sistematis) diperoleh nilai $\boldsymbol{z}$-value $=3.39661>1.96$ atau $\mathrm{z}(\boldsymbol{p}$-value $)=0.000334<0.05$, maka dapat disimpulkan bahwa Y1 (Risiko Sistematis) memediasi pengaruhnya terhadap Y2 (Harga Saham). Pengujian dengan Sobel Test ini sesuai dengan pengujian cara perkalian koefisien seperti di atas.

Pembahasan. Pengujian Hipotesis 1. Hipotesis pertama pada penelitian ini adalah inflasi berpengaruh positif terhadap risiko sistematis. Berdasarkan hasil uji statistik 
diperoleh bahwa inflasi berpengaruh positif dan signifikan terhadap risiko sistematis. Sehingga hipotesis pertama dapat diterima. Kondisi perekonomian memburuk yang ditandai terlalu tingginya inflasi dapat mengakibatkan turunnya pendapatan riil yang diperoleh investor dari investasi, sehingga hal ini akan merupakan sinyal negatif, dan pada akhirnya risiko sistematis meningkat. Sebaliknya, jika inflasi suatu negara mengalami penurunan, maka hal ini akan merupakan sinyal yang positif bagi investor seiring dengan turunnya risiko daya beli uang dan risiko penurunan pendapatan riil, sehingga menyebabkan risiko sistematis menurun. Di mana hasil penelitian ini sejalan dengan penelitian yang dilakukan oleh Ardwita (2016) yang menemukan, inflasi berpengaruh positif dan signifikan terhadap risiko sistematis.

Pengujian Hipotesis 2. Hipotesis kedua pada penelitian ini adalah kurs berpengaruh positif terhadap risiko sistematis. Berdasarkan hasil uji statistik diperoleh bahwa kurs berpengaruh positif dan signifikan terhadap risiko sistematis. Sehingga hipotesis kedua dapat diterima. Kurs rupiah terhadap mata uang asing yang menguat akan menurunkan biaya impor bahan baku untuk produksi, dan akan menurunkan tingkat suku bunga yang berlaku. Demikian sebaliknya bagi investor sendiri, depresiasi rupiah terhadap dollar menandakan bahwa prospek perekonomian Indonesia suram (Sunariyah, 2013). Sebab depresiasi rupiah dapat terjadi apabila faktor fundamental perekonomian Indonesia tidaklah kuat, sehingga dolar Amerika akan menguat dan akan menurunkan kinerja di BEI, hak ini merupakan sinyal negatif bagi investor, sehingga menyebabkan risiko sistematis meningkat. Hasil penelitian ini sejalan dengan penelitian yang dilakukan oleh Ardwita (2016) yang menemukan kurs berpengaruh positif dan signifikan terhadap risiko sistematis.

Pengujian Hipotesis 3. Hipotesis ketiga pada penelitian ini adalah suku bunga berpengaruh positif terhadap risiko sistematis. Berdasarkan hasil uji statistik diperoleh bahwa suku berpengaruh negatif dan signifikan terhadap risiko sistematis. Sehingga hipotesis ketiga tidak diterima. Penelitian ini sejalan dengan penelitian yang dilakukan oleh Fiitriawati (2009) yang menemukan tingkat suku bunga berpengaruh negative signifikan terhadap risiko sistematis. Secara teoritis perubahan suku bunga akan mempengaruhi harga saham secara terbalik, citeris paribus. Artinya, jika suku bunga meningkat, maka harga saham akan turun, citeris paribus, demikian pula sebaliknya. Seperti yang dikemukakan oleh Halim (2005), risiko tingkat bunga merupakan risiko yang timbul akibat perubahan tingkat bunga yang berlaku di pasar modal. Logika hubungan antara suku bunga dengan risiko yaitu, ketika Bank Indonesia menaikan suku bunga (BI rate), maka akan diikuti oleh bank umum dengan menaikan suku bunga simpanan (deposito dan tabungan) untuk masyarakat. Hal ini akan menyebabkan investor menarik investasinya pada saham dan mengalihkannya pada pasar uang dalam bentuk deposito ataupun tabungan, sehingga akan terjadi penurunan permintaan akan investasi saham di pasar modal, dan berdampak terhadap volatilitas harga saham yang akhirnya akan meningkatkan risiko.

Hasil penelitian ini membuktikan bahwa suku bunga berpengaruh negatif terhadap risiko sistematis, artinya jika suku bunga (BI rate) meningkat akan menyebabkan risiko sistematis menurun. Hal ini disebabkan karena naiknya BI rate tidak begitu signifikan yang menyebabkan investor tidak tertarik untuk investasi di pasar uang, sehingga tidak menyebabkan harga saham bervolatilitas, dan akhirnya risiko sistematis menurun. 
Disamping itu bagi investor yang beragama Islam yang berinvestasi pada saham-saham yang berbasis syariah yang menerapkan syariat tidak terpengaruh oleh meningkatnya BI rate yang berbasis riba.

Pengujian Hipotesis 4. Hipotesis keempat pada penelitian ini adalah risiko sistematis berpengaruh negatif terhadap harga saham. Berdasarkan hasil uji statistik diperoleh bahwa risiko sistematis berpengaruh negatif dan signifikan terhadap harga saham. Sehingga hipotesis keempat diterima. Penelitian ini sejalan dengan penelitian yang dilakukan oleh Rahmani dkk (2017) yang menemukan risiko sistematis (beta) berpengaruh negatif signifikan terhadap harga saham. Husnan (2005) mengemukakan, faktor yang memengaruhi risiko sistematis diantaranya Cyclicality. Faktor ini menunjukkan seberapa jauh suatu perusahaan dipengaruhi oleh konjungtur perekonomian. Jika kondisi perekonomian membaik, semua perusahaan akan merasakan dampak positifnya yang menyebabkan risiko sistematis menurun, sehingga berdampak positif terhadap harga saham. Demikian pula pada saat resesi semua perusahaan akan merasakan dampak negatifnya yang menyebabkan risiko sistematis meningkat, sehingga berdampak negatif terhadap harga saham. Logika hubungan antara risiko sistematis dengan harga saham yaitu, ketika kondisi ekonomi memburuk menjadi sinyal negatif bagi investor saham, karena akan merugikan mereka kalau masih atau akan berinvestasi pada saham, akibatnya investor akan menjual sahamnya dan bagi calon investor tidak berminat investasi pada saham, akibatnya akan terjadi kelebihan suplai dari pada permintaan saham, pada gilirannya akan terjadi peningkatan volatilitas harga saham atau risiko yang meningkat, dan akhirnya harga saham akan turun.

Pengujian Hipotesis 5. Risiko sistematis memediasi pengaruh Inflasi, Kurs dan Suku Bunga terhadap harga saham. Dari hasil pengujian hipotesis diketahui variabel inflasi dan kurs berpengaruh positif signifikan terhadap risiko sistematis yang berarti sesuai hipotesis, maka dapat digunakan sebagai variabel dalam analisis jalur. Sedangkan variabel suku bunga berpengaruh negatif tidak signifikan terhadap risiko sistematis yang berarti tidak sesuai hipotesis, maka tidak dapat digunakan sebagai variabel dalam analisis jalur. Selanjunya dari pengujian hipotesis diketahui risiko sistematis berpengaruh negatif signifikan terhadap harga saham, maka dapat digunakan sebagai variabel mediasi dalam analisis jalur.

Dari hasil pengujian Sobel test statistik variabel risiko sistematis dapat memediasi pengaruh inflasi dan kurs terhadap harga saham, artinya inflasi dan kurs mempunyai pengaruh tidak langsung terhadap harga saham. Adanya pengaruh tidak langsung ini diperkuat oleh pengaruh langsung inflasi dan kurs yang tidak signifikan terhadap harga saham seperti terlihat pada tabel 6 , dimana nilai probability lebih besar dari $\alpha=0.05$.

Variabel risiko sistematis dapat memediasi pengaruh inflasi terhadap harga saham, hal ini memberi makna naik turunnya harga saham disebabkan oleh faktor inflasi melalui risiko sistematis. Artinya sebelum inflasi berdampak terhadap harga saham terlebih dahulu akan berdampak terhadap risiko sistematis. Bagi investor yang akan berinvestasi saham yang berbasis syariah di pasar modal terlebih dahulu akan mengamati lebih fakus faktor risiko sistematis, jika risiko sistematis stabil itu artinya kondisi inflasi tidak terlalu tinggi, maka hal akan menjadi sinyal positif bagi investor, sehingga harga saham akan meningkat. Namun jika risiko sistematis meningkat itu artinya kondisi inflasi berpengaruh cukup 
serius, maka hal akan menjadi sinyal negatif bagi investor, sehingga harga saham akan menurun.

Variabel risiko sistematis dapat memediasi pengaruh kurs terhadap harga saham, hal ini memberi makna naik turunnya harga saham disebabkan oleh faktor kurs melalui risiko sistematis. Artinya sebelum kurs berdampak terhadap harga saham terlebih dahulu akan berdampak terhadap risiko sistematis. Bagi investor yang akan berinvestasi saham yang berbasis syariah di pasar modal terlebih dahulu akan mengamati lebih fakus faktor risiko sistematis, jika risiko sistematis stabil itu artinya kondisi kurs tidak terlalu tinggi, maka hal akan menjadi sinyal positif bagi investor, sehingga harga saham akan naik. Namun jika risiko sistematis meningkat itu artinya kondisi kurs berpengaruh cukup serius, maka hal akan menjadi sinyal negatif bagi investor, sehingga harga saham akan menurun.

\section{Simpulan Dan Keterbatasan}

\section{Simpulan}

Penelitian ini bertujuan menguji pengaruh Inflasi, Kurs dan Suku Bunga terhadap Risiko Sistematis, Risiko Sistematis terhadap Harga Saham dan pengaruh Inflasi, Kurs dan Suku Bunga terhadap Harga Saham melalui Risiko Sistematis dengan studi empiris pada saham-saham Jakarta Islamic Index di Bursa Efek dengan menerapkan model regresi data panel common effect. Metode regresi data panel merupakan kombinasi dari data time series dengan sepuluh periode pengamatan (2013-2018) dan data cross section dengan 41 saham syariah yang terpilih sebagai sampel penelitian. Hasil penelitian ini menemukan Inflasi berpengaruh positif dan signifikan terhadap Risiko Sistematis. Kurs berpengaruh positif dan signifikan terhadap Risiko Sistematis. Suku Bunga berpengaruh negatif dan signifikan terhadap Risiko Sistematis. Risiko Sistematis berpengaruh negatif dan signifikan terhadap Harga Saham. Risiko Sistematis memediasi pengaruh Inflasi dan Kurs terhadap Harga Saham.

\section{Keterbatasan dan Saran.}

Dalam rangka untuk pengembangan lebih lanjut dari hasil penelitian ini, maka dapat mempertimbangkan variabel lain yang diduga dapat memengaruhi Risiko Sistematis dan Harga Saham. Jumlah sampel untuk penelitian selanjutnya dapat menambah sampel dengan menambah periode penelitian. Model analisis dalam penelitian ini menggunakan data panel dengan metode common effect, bagi penelitian yang akan datang dapat mempertimbangkan metode fixed effect atau random effect, sebagai upaya untuk mendapatkan hasil analisis data yang lebih akurat. 


\section{Referensi}

Ardwita YF. 2016. Analisis Pengaruh Variabel Fundamental Perusahaan dan Makro Ekonomi terhadap Risiko Sistematis Pasar Modal Konvensional dan Syariah. Jurnal Ilmiah Mahasiswa Fakultas Ekonomi dan Bisnis. Universitas Brawijaya. Malang. Vol 6 No 2 (2016)

Agusto OR.S. 2018. Analisis Pengaruh Faktor Profitabilitas dan Risiko Sistematis terhadap Harga Saham Properti di Bursa Efek Indonesia. Tesis. Program Pascasarjana Magister Manajemen Fakultas Ekonomi dan Bisnis Universitas Lampung. Bandar Lampung

Alwi, Iskandar Z. 2008. Pasar Modal Teori dan Aplikasi, Yayasan Pancur Siwah. Jakarta

Blanchard, Olivier. 2006. Macroeconomic, $4^{\text {th }}$ ed., Prentice Hall, New Jersey

Fahmi, Irham. 2014. Manajemen Keuangan Perusahaan Dan Pasar Modal. Mitra Wacana Media. Jakarta

Ferranti D. dan Yunita I. 2015. Analisis Pengaruh Inflasi, Tingkat Suku Bunga, Dividend Payout Ratio, dan Current Ratio terhadap Risiko Sistematis (Studi pada Perusahaan BUMN yang Terdaftar di Bursa Efek Indonesia periode 2011-2013). Jurnal eProceeding of Management : Vol.2, No.2 Agustus 2015

Fitriawati. 2009. Pengaruh Uang Yang Beredar (M2), Kurs, Inflasi, dan Tingkat Buku Bunga SBI Terhadap Beta Saham Syariah (JII) dan Indeks Harga Saham Gabungan (IHSG) http://repository.uinjkt.ac.id

Conway, Edmund. 2009. 50 Gagasan Ekonomi yang Perlu Anda Ketahui. Esensi. Jakarta

Ghozali, Imam. 2014. Ekonometrika Teori, Konsep dan Aplikasi dengan IBM SPSS 22, Universitas Diponegoro. Semarang

Jogiyanto, Hartono. 2017. Teori Portofolio dan Analisis Investasi. Edisi kesepuluh, BPFE. Yogyakarta

Julduha, Nucifera dan Indra Kusumawardhani. (2013). Pengaruh Net Profit Margin, Current Ratio, Debt to Assets, dan Tingkat Suku Bunga terhadap Beta Saham Syariah. Jurnal Buletin Studi Ekonomi - Volume 18 Nomor 2, 144-152

Halim, Abdul, (2005), Analisis Investasi. Edisi ke-2, Salemba Empat, Jakarta

Husnan, Suad. 2005. Dasar-dasar Teori Portofolio dan Analisis Sekuritas. Edisi kelima. BPFE. Yogyakarta

Keown Arthur J, Martin John D, Petty William, Scott, JR. 2004. Financial Management : Priciples and Application (Manajemen Keuangan : Prinsip-Prinsip dan Aplikasi), Edisi Kesembilan, Prentice Hall. Edisi Indonesia Penerbit PT Indeks. Jakarta

Kismawad E. 2013. Pengaruh Variabel Makro Ekonomi Terhadap Jakarta Islamic Index. Tesis. Program Pascasarjana Institut Agama Islam Negeri Sumatera Utara. Medan

Nopirin. 2012. Ekonomi Moneter, Buku I dan II, Edisi ke 1, Cetakan kesepuluh, BPFEUGM. Yogyakarta 
Pangemanan, Vanessa. 2013. Inflasi, Nilai Tukar, dan Suku Bunga terhadap Risiko Sistematis. Jurnal EMBA - Volume 1 Nomor 3, 189-196.

Peraturan OJK Nomor 17/POJK.04/2015 tentang Penerbitan dan Persyaratan Efek Syariah Berupa Saham oleh Emiten Syariah atau Perusahaan Publik Syariah.

Peraturan OJK Nomor 35/POJK.04/2017 tentang Kriteria dan Penerbitan Daftar Efek Syariah

Rahmani D.A, Nugraha, dan Waspada IP. 2017. Pengaruh Faktor-Faktor Fundamental dan Risiko Sistematis terhadap Harga Saham. Jurnal Ilmu Manajemen dan Bisnis. Vol 8, No 1 (2017)

Sarumaha A.2017. Analisis Pengaruh Makro Ekonomi dan Faktor Fundamental Perusahaan terhadap Beta saham pada Industri Pertambangan yang Terdaftar di Bursa Efek Indonesia. Jurnal Ilmiah WIDYA Ekonomika. Volume 1 Nomor 2 Juli 2017

Salvatore, D.1997. Ekonomi Internasional (International Economic), Edisi kelima, Jilid 1. Erlangga. Jakarta

Sudiyatno, Bambang dan Cahyani Nuswandhari. 2009. Peranan Beberapa Indikator Ekonomi DalamMempengaruhi Risiko Sistematis Jurnal Dinamika Keuangan dan Perbankan - Volume 1 Nomor 2, 66-81

Sukirno, Sadono. 2011. Makro Ekonomi Teori Pengantar. Edisi Ketiga. Rajawali Pers. Jakarta

Sunariyah. 2013. Pengantar Pengetahuan Pasar Modal. Edisi Keenam, UPP STIM YKPN. Yogyakarta

Tandelilin, Eduardus. 2010. Portofolio dan Analisis Investasi Teori dan Aplikasi, Edisi Pertama. Kanisius. Yogyakarta

Utami A. T dan Herlambang L. 2016. Pengaruh Variabel Makro Ekonomi Terhadap Indeks Jakarta Islamic Index (JII) Periode Januari 2010 Hingga November 2015. Jurnal Ekonomi Syariah Teori dan Terapan. Vol 3, No 1 (2016) 